\title{
"TICOS AUTÉNTICOS... QUE NO HABLAN ESPAÑOL" IDEOLOGÍAS SOBRE LAS LENGUAS MINORITARIAS Y LA DIVERSIDAD LINGÜÍSTICA DE COSTA RICA ${ }^{1}$
}

\author{
Carlos Sánchez Avendaño
}

\begin{abstract}
RESUMEN
En el presente artículo se analizan algunas ideologías lingüísticas en fuentes escritas (discurso académico, prensa escrita, textos escolares y crónicas de viaje) con respecto a las lenguas indocostarricenses, el inglés criollo limonense y la lengua de señas costarricense. Básicamente se tratan con detalle los siguientes ejes ideológicos: la superioridad lingüística y los tipos de lenguas, la relación entre lenguaje y capacidades cognitivo-intelectuales, la conexión entre variación idiomática y escritura, y la relación entre lengua e identidad.

Palabras clave: sociolingüística, ideologías lingüísticas, ideología de la superioridad lingüística, identidad y lenguaje, lenguas de Costa Rica.
\end{abstract}

\begin{abstract}
This article analyzes some linguistic ideologies in written sources (academic discourse, press, school textbooks and journey chronicles) concerning the Costa Rican indigenous languages, the Limon creole English and the Costa Rican sign language. Basically, the following ideological axis are commented: the linguistic superiority and the types of languages, the relation between language and cognitive-intellectual capacities, the link between linguistic variation and writing, and the relationship between language and identity.

Key words: sociolinguistics, language ideologies, ideology of linguistic superiority, identity and language, languages of Costa Rica.
\end{abstract}

\section{Introducción}

En el presente artículo, nos ocupamos de analizar discursos "claves" relativos a las lenguas de Costa Rica: noticias y reportajes de la prensa escrita; crónicas de viaje; artículos, ensayos, tesis y libros de naturaleza académica; y libros de texto escolares. Todos estos documentos, en conjunto, nos ayudan a establecer, a partir del examen de los modelos cognitivos de sus autores ${ }^{2}$, los grandes ejes ideológicos que se manifiestan en torno a las lenguas de Costa Rica desde distintas perspectivas: la anónima y supuestamente imparcial propia del discurso

Dr. Carlos Sánchez Avendaño. Profesor de la Escuela de Filología, Lingüística y Literatura de la Universidad de Costa Rica. Investigador del Instituto de Investigaciones Lingüísticas.

Correo electrónico: tocumarama@yahoo.es

Recepción: 29- 05- 2013

Aceptación: 02- 06- 2013 
periodístico, la didáctica y presumiblemente objetiva del discurso escolar, la científica y supuestamente desprejuiciada del discurso académico, y la más subjetiva de la crónica de viajes.

Dado que el examen de las ideologías preponderantes en lo relativo a las variedades locales del español costarricense ya ha sido realizado con detalle por otros autores (v.g. Quesada 1992, Jara 2006), en el presente trabajo abordamos el tema en lo que respecta a las otras lenguas del país; a saber, los idiomas indocostarricenses (boruca o brunca, bribri, buglere o bocotá, cabécar, chorotega, huetar, malecu o guatuso, nove o guaymí, térraba), el inglés criollo limonense y la lengua de señas costarricense (LESCO) ${ }^{3}$.

\section{Las ideologías lingüísticas}

Al analizar las creencias que surgen como consecuencia del contacto entre lenguas en comunidades multilingües, las ideologías que más llaman la atención son aquellas relativas a las concepciones de qué cuenta como un idioma (incluyendo las ideas sobre la posesión de gramática -o gramática compleja-, acerca de la cantidad de vocabulario y de un sistema de escritura, como parámetros para decidir sobre esta cuestión), los valores asociados con variedades lingüísticas concretas (las creencias de que una variedad lingüística es mejor, más expresiva, más objetiva, más científica, más pura, más correcta, etc.), y la idea de que determinados usos lingüísticos sirven como indicadores de identidad (Woolard 1998).

Según Kroskrity (2000b) -y así se constatará a lo largo del presente trabajo-, las ideologías del lenguaje deben concebirse como una amalgama de cuatro dimensiones convergentes. En primer lugar, representan la percepción sobre el discurso y el lenguaje con base en el interés de un grupo social específico. En este sentido, lo que una persona considera "verdadero", "bueno" o "bonito" en relación con una lengua se basa en su experiencia social y por lo común se encuentra ligado a sus intereses económico-políticos, de manera que las ideologías sirven como instrumentos de dominación simbólica para promover, legitimar y proteger dichos intereses.

En segundo lugar, resulta más provechoso considerar que las ideologías lingüísticas son múltiples, dada la multiplicidad de divisiones sociales significativas (v.g. género, generación) dentro de los grupos socioculturales con el potencial de producir perspectivas divergentes y expresarlas como índices de pertenencia grupal. Así, se subraya el hecho de que las ideologías del lenguaje se basan en la experiencia social. Esta consideración también sirve para tomar muy en cuenta la "naturalización" de las ideologías dominantes por parte de la mayoría de los miembros, sea que estas hayan emergido en el propio grupo (Kroskrity 2000c) o que provengan de otro colectivo hegemónico que las inculca por medio de tecnologías como la escritura o de nuevos valores (religiosos, económicos, etc.) ajenos al sistema de vida tradicional, tras lo cual se llega a erosionar la cultura vernácula a favor del grupo que controla los nuevos recursos (Schieffelin 2000).

En tercer lugar, conviene no perder de vista que los miembros de un mismo grupo pueden mostrar grados variados de conciencia de las ideologías lingüísticas locales. A este respecto, es cierto que las ideologías pueden ser explícitas, pero también se encuentran de manera implícita en los usos reales. Esta distinción se puede corresponder con las creencias más conscientes de las que echan mano las personas con fines reivindicativos o contestatarios, por un lado, y con las creencias puramente prácticas que no se ponen en duda y que se conciben como naturales, por otra parte. 
En cuarto lugar, las ideologías lingüísticas median entre las estructuras sociales y las formas de habla. Las ideologías unen la experiencia sociocultural y los recursos lingüísticodiscursivos con que cuentan las personas, de manera que estos últimos se seleccionan y se constituyen en índices ligados a rasgos de la experiencia, con lo cual también se llega a pensar que un elemento lingüístico particular de una lengua debe revelar una característica de sus hablantes o de su modo de vida.

\section{Fuentes escritas para el estudio de las ideologías sobre la diversidad linguística y las lenguas minoritarias de Costa Rica}

En el presente estudio nos decantamos por analizar discursos "claves", por su valor como difusores, afianzadores y legitimadores de representaciones sociales hegemónicas. Por este motivo, nuestro corpus está conformado por los discursos de académicos, intelectuales, viajeros o cronistas, periodistas ${ }^{4}$, educadores y textos escolares ${ }^{5}$ e instituciones públicas.

Debe entenderse que el estudio de las creencias sobre las lenguas implica una revisión minuciosa de los textos con el fin de detectar tanto proposiciones ideológicas explícitas como ideologías subyacentes. En algunos discursos, tales ideologías se desarrollan de modo amplio, mientras que en otros apenas si aparecen tangencialmente. Es por eso que, en realidad, usualmente nos encontramos con "trozos" de esquemas ideológicos, indicios inmersos en un mar de descripciones y datos, especialmente si el material analizado no se ocupa de lo lingüístico de manera particular, como ocurre, por ejemplo, con las crónicas de viajes. Por este motivo, estamos muy claros de que presentamos un esbozo armado a partir de "retazos" de discursos de diversas procedencias.

\section{Ejes ideológicos fundamentales con respecto a las lenguas minoritarias y la diversidad linguiística de Costa Rica}

En el presente apartado analizaremos con detalle cada uno de los ejes ideológicos que se encuentran en nuestro corpus. Básicamente, se reconocen dos complejos ideológicos fundamentales: el de la jerarquía lingüística y la naturaleza o tipología de las lenguas, y el de la relación entre lengua e identidad.

Para efectos de la presente exposición, podemos distinguir tres etapas o épocas en la lingüística costarricense ocupada de las lenguas minoritarias del país. Esta periodización debe tenerse presente con el fin de comprender mejor la aparición de proposiciones ideológicas explícitas de índole valorativa en los académicos cuyas publicaciones datan de las décadas previas a 1970:

a. Finales del siglo XIX y primeros años del siglo XX: trabajo empírico de documentación y descripción llevado a cabo por académicos extranjeros.

b. Primera mitad del siglo XX: trabajo de documentación y descripción llevado a cabo, sobre todo, por académicos costarricenses, aunque con la participación de extranjeros, con ya algún sustento científico, pero sin basarse teórica o metodológicamente aún en la lingüística de modo sistemático.

c. Segunda mitad del siglo XX y primeros años del siglo XXI: trabajo de documentación y descripción llevado a cabo, principalmente, por académicos costarricenses con formación en lingüística. 


\subsection{El complejo ideológico de la jerarquía lingüística y la naturaleza de las lenguas}

A partir del siglo XVIII, se acuñó explícitamente la distinción entre "lenguas civilizadas" o "lenguas cultas" -las propias de las metrópolis europeas- y "lenguas primitivas" -habladas en las colonias-. Los criterios en los que se basaba esta categorización comprendían la existencia de literatura escrita y la suposición de que los verdaderos idiomas tenían gramática (entendida esta como una norma fijada y expuesta en un libro), mientras que los códigos comunicativos de los pueblos "salvajes" carecían de esta (Crystal 1995, Bernández 2004). Además, las lenguas primitivas se caracterizarían por la simplicidad de su gramática y por un repertorio léxico de apenas algunos cientos de vocablos (Crystal 1995, Wilson 1996). Por este motivo, las lenguas vernáculas de los pueblos conquistados fueron ubicadas en un rango inferior dentro de la jerarquía lingüística surgida como consecuencia de la expansión europea.

A este respecto, Dorian (1998) apunta que, en los territorios de asentamiento europeo, resultaron muy dañinas las ideologías occidentales hacia la diversidad lingüística, tales como la ideología del desprecio, según la cual las lenguas propias de grupos sin poder fueron objeto de menosprecio en el sistema de estratificación lingüística, tras sufrir de la transferencia de prestigio, proceso mediante el cual el prestigio de los grupos que ostentan el poder económico, político o militar se transfiere a sus atributos, como los idiomas. De ello se derivó que los idiomas de minorías étnicas se consideraran rudimentarios e inadecuados para organizar el mundo.

Del mismo modo, sobre todo durante el siglo XIX, en la investigación etnológica mayoritariamente se aceptaban los postulados evolucionistas. Estos, según explica Mercier (1976), consistían en la simplificación etnocéntrica de la historia de la humanidad en etapas de desarrollo, de manera que se consideraba que las diversas sociedades humanas se encontraban básicamente en dos estadios evolutivos culturales: las sociedades civilizadas y las sociedades primitivas. Así, todas las apreciaciones valorativas sobre el mayor o menor progreso de un grupo cultural partían de esta jerarquización apriorística, acerca de la cual intentaron teorizar numerosos trabajos antropológicos.

En este apartado veremos cómo se manifiesta este complejo ideológico en la descripción y en la valoración de las lenguas minoritarias de Costa Rica.

\subsubsection{La ideología de la superioridad de las lenguas}

En nuestro corpus, la ideología de la superioridad de las lenguas se manifiesta en la forma de dos "teorías": una acerca de la complejidad lingüística (existen lenguas "primitivas" o "salvajes" y lenguas "civilizadas" o "cultas" -en correlación con criterios como la regularidad gramatical y el caudal léxico-) y otra sobre la categorización de las variedades linguísticas (existen "lenguas" frente a "dialectos" o "lenguajes" -es decir, una categoría idiomática algo indefinida que agrupa lo que hablan los grupos humanos considerados inferiores-).

\subsubsection{Lenguas primitivas o salvajes frente a idiomas civilizados y cultos}

En lo que respecta a las lenguas vernáculas de los pueblos indocostarricenses, la manifestación del complejo ideológico de la jerarquía lingüística se puede apreciar con solo echar un vistazo a los primeros trabajos y referencias a estos idiomas en las publicaciones de finales del siglo XIX y la primera mitad del siglo XX. La dicotomía entre "lenguas primitivas, salvajes o 
bárbaras" y "lenguas civilizadas o cultas" aparece, implícita o explícitamente, en varios trabajos de índole académica (Gabb 1875, Pittier y Gagini 1892, Gagini 1917, Pittier 1941, Yglesias 1942).

En la concepción de estos autores, el "primitivismo" o "salvajismo" lingüístico se asocia con los más variados rasgos culturales e intelectuales, siempre en contraposición con las lenguas de las sociedades "civilizadas". Por ejemplo, Gagini aduce que las lenguas bárbaras, como el térraba, responden a factores relativos a la "imaginación" y la "naturaleza" y no a la "ciencia":

\footnotetext{
Estudio en alto grado interesante sería seguir paso á paso las variadísimas acepciones metafóricas que van tomando las palabras en los idiomas bárbaros, sometidos á la influencia poderosa de la imaginación y de la naturaleza, antes que á los principios científicos. (Pittier y Gagini 1892: 9) ${ }^{6}$
}

De la misma manera, el naturalista suizo Henri Pittier (1941), pese a su espíritu de antropólogo empírico y a su posición crítica con respecto a la supuesta "superioridad" cultural de los pueblos occidentales, no escapó tampoco a la ideología de la jerarquía de las lenguas, como se muestra en el siguiente fragmento, en el cual se asocian las lenguas con la concreción o abstracción cognitiva. El idioma "conveniente" al que se refiere Pittier es probablemente una de las lenguas indoeuropeas habladas por él (francés, alemán, español o inglés); es decir, las lenguas de "los civilizados" -aptas para la codificación del pensamiento abstracto-, en contraposición a las "hablas primitivas" como el bribri y el térraba -propias para la referencia a situaciones de la vida cotidiana, según esta representación sociocognitiva-:

\footnotetext{
[L]legué a expresarme correctamente (si corrección hay en esas primitivas hablas) y sin dificultad tanto en bribrí como en térraba. Al hacer esto, observé un fenómeno interesante: la imposibilidad, al menos para nosotros los civilizados, de pensar en esos idiomas. Mientras tanto se trataba de asuntos, como diré yo, objetivos o materiales, como el relato de una cacería, la expresión de una necesidad, etc., tanto el bribrí como el térraba alcanzaban, pero a la primera abstracción y casi inconscientemente, volvía a entrar el idioma conveniente. (1941: 5)
}

Se infiere, por lo tanto, la consideración de que las "lenguas primitivas" carecen de norma y no "alcanzan" para la codificación del pensamiento abstracto, por lo menos no el de los "civilizados". Más adelante, este mismo autor alude al mayor primitivismo del brunca en comparación con el térraba y el bribri, a raíz de que la presunta falta de gramática (entendida en este caso, según se ve, como conjunto de reglas de cumplimiento sistemático) constituye un signo de menor desarrollo lingüístico. Esto significa que habría grados de "primitivismo" en correlación con rasgos como la regularidad morfológica y, como veremos más adelante, el repertorio léxico:

\footnotetext{
La lengua brunka parece ser más sencilla, más primitiva si se puede decir, que el bribrí o el térraba, en los cuales hay indicios evidentes de sistematización, de reglas gramaticales. Por ejemplo, no he podido formar, como en térraba, grupos de considerable extensión en las [sic] cuales todos los nombres o todos los adjetivos tienen la misma terminación como un significado evidente [...]. Sea como fuere, parece evidente que el idioma brunka es menos avanzado en su evolución que los de los térraba y bribrí. (1941: 10)
}

Del mismo modo, en la primera descripción relativamente completa con la que contamos acerca de los pueblos y lenguas indígenas de Costa Rica, Gabb (1875, 1883) constantemente alude al mayor o menor acercamiento de cada uno de los grupos a la "vida civilizada". Sus comentarios relativos a aspectos concretos de los idiomas frecuentemente aluden a la comparación entre las "lenguas cultas" o "lenguas más civilizadas", por un lado, y las "lenguas indígenas", por otro. Por ejemplo, este autor afirma que el bribri es una lengua "pobre" y se refiere al supuesto repertorio léxico reducido de las lenguas indígenas, uno de los rasgos de las "lenguas primitivas" más comúnmente citados: 
Si se cuentan las pocas palabras abstractas que sin duda se me han escapado, y todos los nombres específicos de animales y plantas (y muchos de estos últimos se forman de un adjetivo, ó del nombre de alguna planta, combinado con wak, tribu), no pienso que la lengua pueda contener dos mil palabras, y quizá ni mil quinientas. (1883: 390) ${ }^{7}$

Cuando Gabb encuentra un dominio semántico en el que la hipótesis de la pobreza léxica de las "lenguas primitivas" no se corrobora, no esconde su estupefacción al respecto. Sin embargo, se puede inferir que la diferencia presuntamente radical entre la riqueza en un ámbito y la pobreza en otro no deja de considerarse una característica de las lenguas ubicadas en el nivel inferior de la jerarquía idiomática:

\begin{abstract}
Es de notar que una lengua [el bribri], por otra parte, tan pobre, á veces va al extremo opuesto. En las lenguas cultas, y notablemente en la castellana, hay una una [sic] gran variedad de palabras para expresar los matices de los colores de los animales, especialmente de los caballos. Estas palabras, originalmente adjetivos, se usan con frecuencia como nombres. Pero en Bribri tenemos ocho nombres para distinguir los cerdos, seís de los cuales son para colores [...]. Las palabras que expresan cualidades físicas de la materia, abundan tanto como en las lenguas más civilizadas, y su uso es tan estrictamente limitado. (1883: 392-393)
\end{abstract}

El reducido caudal léxico como supuesto rasgo característico de las lenguas indocostarricenses aparecerá también en las descripciones de los dos lingüistas del siglo XX que publicaron sus trabajos antes de la década de 1970: Gagini (1917) y Arroyo (1966). Gagini se refiere al sentido extensivo de las palabras del térraba, dada su condición de "lengua salvaje", en contraposición a la riqueza de vocablos para codificar "matices de un concepto", propia de las "lenguas civilizadas":

\footnotetext{
El Térraba, como todas las lenguas salvajes, se vale en muchos casos de términos generales a falta de aquellos que en las lenguas civilizadas marcan los matices de un concepto. Kuota, por ejemplo, designa la piel humana, el pellejo de un animal, la corteza de los árboles, las escamas de los peces, las uñas de los dedos, etc., es decir, todo lo que envuelve o protege; Koguoh es punta, pico de ave, diente, rama de árbol, etc. (1917: 28)
}

También en referencia al térraba, pero incluyendo datos análogos del bribri, el brunca y el cabécar, Arroyo apunta:

\footnotetext{
El vocabulario térraba que presentamos, posiblemente el más extenso anotado hasta hoy, trasluce la pobreza y simplicidad de la lengua, como se habla actualmente. Los nombres de abstracciones no existen en él, son sustituidos por frases u oraciones enteras. Numerosas palabras tienen una acepción amplísima [...].

La partícula -xo es muy corriente y tiene la acepción de carne, sustancia, material; corresponde a las voces xika, del bribri y xeke o xaka del cabécar. Aparece por ejemplo en: ará xó (arena), subí xó (arcilla), xkuí xó (algodón), frün xó (ceniza), drun xó (hierro), u xó (nido), vaca norio xó (sustancia de leche de vaca: queso), etc.

La voz -kuota, que en ocasiones se reduce a kuo, como kuás en brunka o kuo en bribri, tiene el significado radical de superficie, exterior, cáscara; la encontramos en la composición de: kor kuota (corteza de árbol), sap kuota (casco), fru kuo (cuero), bob kuota (párpado), etc. Sin embargo, la forma kuo entra en la formación de numerosos nombres de objetos redondeados y algunas veces un poco modificada se presenta en los nombres de diversos órganos o partes del cuerpo humano. (1966: 117-118)
}

En realidad, en muchos de los ejemplos aportados, tanto Gagini (1917) como Arroyo (1966), así como décadas atrás lo habían hecho tanto Gabb $(1975,1883)$ como Pittier y Gagini (1892), se refieren a un procedimiento de formación léxica común en muchas lenguas americanas, denominado economía morfoléxica por Constenla ${ }^{8}$ :

[U]na estructuración del léxico tal que, a partir de un número reducido de morfemas léxicos (raíces y elementos derivativos), se producen la mayor parte de los lexemas por procedimientos sintácticos o morfológicos (estos últimos derivativos o flexivos) regulares y transparentes. (1992: 102) 
De este modo, se aprecia que autores como Gabb (1875), Gagini (1917) y Arroyo (1966) interpretaron como pobreza léxica la tendencia que notaron en el caso del bribri, el térraba, el cabécar y el boruca a codificar contenidos semánticos por medio de la estrategia de composición o mediante grupos nominales en los que entran en juego dos sustantivos en relación posesiva. Estos contenidos se codifican en muchos idiomas indoeuropeos mediante lexemas distintos, así que el linguocentrismo europeo fue el motivo de la interpretación de la economía morfoléxica de las lenguas indocostarricenses como un rasgo de "primitivismo".

En nuestra opinión, estamos ante un principio ideológico habitual en la valoración de las diferencias entre las lenguas: aquellos fenómenos o mecanismos propios de la lengua materna (extensible también a las segundas lenguas que una persona domine, sobre todo si están relacionadas genéticamente o si muestran coincidencias tipológicas) se consideran más "naturales", "lógicos" o "adecuados" que los propios de otros idiomas que difieran al respecto9.

Otras características de las consideradas "lenguas primitivas" guardan relación con los componentes fonológico, gramatical y semántico. En cuanto al primero, los autores que se ocuparon de describir los idiomas indocostarricenses antes de la década de 1970 aluden, sobre todo, a la inestabilidad de la pronunciación (Thiel 1882; Pittier 1895, 1941; Gagini 1917; Arroyo 1966), si bien es preciso señalar que en este caso la valoración de este fenómeno como característico de las lenguas primitivas es menos explícito que en el caso del léxico -ya comentado-, como se aprecia en la siguiente afirmación de Arroyo:

\footnotetext{
Una característica común a todas las lenguas en estudio es su inestabilidad fonética. Una misma palabra es pronunciada en diferente forma por los habitantes de las diversas rancherías; hay diferencias fonéticas familiares y hasta individuales que dificultan la comprensión de los vocablos. (1966: 16-17)
}

En Pittier, tal estabilidad se atribuye al carácter ágrafo de estos idiomas, puesto que este intelectual considera que la "fijeza" de la pronunciación está vinculada a la escritura. Nótese, por ende, que aquí se plasma una nueva dicotomía: lenguas ágrafas -caracterizadas por la inestabilidad fonética- frente a lenguas escritas - caracterizadas por la fijeza fonética-:

\footnotetext{
Es de notarse que, en los idiomas de Talamanca como en todos los que no se escriben, la pronunciación de las vocales y consonantes dista mucho de tener la fijeza acostumbrada en los idiomas escritos. La $a$, la $e$, la $\ddot{e}$ se confunden muy á menudo; no es siempre fácil tampoco distinguir entre la $\ddot{e}$ y la $i$, y hay un pasaje casi insensible de ciertas consonantes en otras, de tal modo que una misma sílaba puede escribirse sin dejar de ser inteligible con $m, b, p, b, l, r$ y $d$ indiferentemente, siendo, sin embargo, de más especial frecuencia el cambio de $m$ en $b$ y $p$, y de $d$ en $l$ y $r$. (1895: 13)
}

La inestabilidad en la pronunciación que aduce Pittier en el pasaje anterior en realidad consiste en un fenómeno de alternancia morfofonológica común en muchas lenguas indocostarricenses, según la cual, por ejemplo, el fonema /b/ se realiza como $[\mathrm{b}]$ o $[\mathrm{m}]$, mientras que /d/ se realiza como [d], [n] o [0], dependiendo del entorno fónico tanto en cabécar (Margery 1989) como en bribri (Constenla et al. 1998). Además de la alternancia morfofonológica, común por lo demás en las lenguas del mundo, se valoran como manifestaciones de la "inestabilidad fonética" otros fenómenos fonológicos propios de la realización oral de cualquier idioma, como ocurre en Thiel:

Hablando con un indígena y pronunciándole el vocablo como se escribe, suele muchas veces no entenderlo. Esto proviene, según las observaciones del docto Brasseur de Bourbourg, autor de una gramática Quiché, de que uno no pronuncia la palabra de aquel modo con que los indios entre sí hablando, sincopan y cortan todos los vocablos al pronunciarlos. Cuando se pronuncian enteros, extrañan y dudan de una ú otra cosa que se les dice". (1882: 4) 
Apréciese, por consiguiente, cómo, aunque no se valora explícitamente en términos de primitivismo la presunta "inestabilidad fonética" de los idiomas indocostarricenses, sí se describe como un fenómeno del habla de los indígenas (como sucede en Thiel 1882) o de los hablantes de lenguas ágrafas (como sucede en Pittier 1895), como si tales fenómenos de alternancia no se produjeran en las lenguas indoeuropeas o en las lenguas de tradición escrita, de modo que implícitamente sí existe una valoración cimentada en la ideología de la jerarquía lingüística.

En lo relativo al componente gramatical, se encuentran alusiones a la simplicidad (Gabb 1875, Pittier y Gagini 1892) y a la conexión entre gramática y "grado de cultura" (Pittier y Gagini 1892), pero, particularmente, sobresale la tendencia de describir las lenguas indocostarricenses a partir de su carencia de fenómenos o rasgos propios de las lenguas indoeuropeas o lo que se espera de las "lenguas primitivas" (Gabb 1875, Gagini 1917, Arroyo 1966). Por ejemplo, en Gabb (1875, 1883), son constantes las referencias a la simplicidad morfológica del bribri y los demás idiomas de la "familia costarricense", en contraposición con la multiplicidad de tiempos verbales que, según Humboldt, caracterizaría a "las lenguas más bárbaras de América" (1883: 396).

El ligamen entre el "grado de cultura" y los mecanismos morfosintácticos de codificación de significado es expuesto de modo explícito por Gagini (Pittier y Gagini 1892) como una especie de teoría general acerca de las lenguas y en referencia al térraba. Si bien este autor no explicita cuál es la dirección del continuum cultural correlativo al procedimiento morfosintáctico para formar el plural (es decir, cuál de los procedimientos 1, 2 o 3 en el párrafo que se transcribe a continuación revela el mayor o menor "grado de cultura"), se puede inferir que el mecanismo más "culto" corresponde al propio del español (esto es, el empleo de inflexiones específicas para tal propósito), de modo que el térraba tendería al grado de cultura intermedio (la expresión del plural mediante un morfema libre) con resabios aún del grado inferior (la duplicación):

\footnotetext{
El plural se forma en los idiomas por uno de estos tres procedimientos, según su grado de cultura: $\mathrm{I}^{\circ}$ repitiendo simplemente el nombre; $2^{\circ}$ por medio de una palabra auxiliar que signifique varios, algunos, todos, etc.; $3^{\circ}$ con una terminación ó inflexión particular.

En Térraba se emplea algunas veces el primer procedimiento, p.ej.: vaca vaca (vacas, un rebaño ó vacada); pero el usual es el segundo, que consiste en añadir al nombre la palabra bëga, v.gr.: angua (niño), angua bëga (niños), ó un adjetivo numeral si los objetos son tan pocos que pueden contarse á primera vista. (1892: 12-13)
}

Por lo demás, como ya adelantamos, predomina la descripción de la gramática de los idiomas indocostarricenses por medio de lo que podríamos denominar una estrategia de negación: se describe a partir de las categorías morfosintácticas de las lenguas indoeuropeas (particularmente el español) ausentes en la lengua indígena. Por inocente que pueda parecer este procedimiento, en realidad está basado en un canon ideológico de lo que se espera de una lengua "civilizada" o "de cultura", de manera que se juzga que no son indicios de inferioridad lingüística de los idiomas indocostarricenses los fenómenos que también se encuentran en lenguas de prestigio, mientras que las características divergentes sí se valoran en términos estéticos o de desarrollo cultural o intelectual, como se puede inferir de lo anotado por Gagini:

\footnotetext{
En la lengua de Térraba se hallan todas las partes de la oración castellana, excepto el artículo y la conjunción: el primero falta igualmente en otros muchos idiomas, como el latín; la segunda no es indispensable en las lenguas cuya sintaxis carece de artificiosa elegancia y de construcciones complicadas. (1892: 12)
} 
Apegadas aún a esta tendencia, encontramos en época reciente -si bien no en publicaciones académicas- proposiciones ideológicas que, pese a que a veces ponderan la riqueza de los idiomas indocostarricenses, expresan la ideología de la superioridad de las lenguas. Un buen ejemplo está constituido por la siguiente descripción del educador Guido Barrientos, quien sostiene que el bribri es una lengua "elemental" por carecer de categorías morfosintácticas del español y por su gran número de palabras onomatopéyicas, lo cual no es óbice para que él la considere "una lengua rica", sin especificar en qué se basa esa valoración:

El bribri es una lengua muy rica, sin embargo es una lengua elemental que carece de artículos, de género y de número. Tiene una gran cantidad de voces onomotopeicas [sic], es decir voces que imitan los sonidos que hay en la naturaleza. Por ejemplo, la palabra en bribri para gallina es dakarò. Suena como la voz de la gallina. Cuando se dice ash' (naranja), se oye una persona chupando la fruta. (citado en Rodríguez 1983: 120)

Finalmente, no faltan las alusiones a la "inestabilidad semántica", rasgo presuntamente común en las lenguas indocostarricenses, de acuerdo con Arroyo:

\footnotetext{
La inestabilidad fonética es también acompañada de la inestabilidad semántica, hecho que hemos podido comprobar con la comparación de los léxicos que anotan los autores ya citados y los vocabularios usados actualmente por los indios en sus diarias conversaciones.

En nuestras lenguas encontramos voces con múltiples y ambiguas acepciones: a veces representan una idea muy amplia [...]. (1966: 17)
}

Este mismo autor constantemente alude a la confusión de conceptos en las lenguas indocostarricenses, como cuando destaca que la palabra para 'azul' en boruca "posiblemente se perdió”, dado que Gabb (1875) consignó uagát pero en sus datos este término se refiere al color 'verde', tras lo que concluye como explicación alternativa que "se confunden ambos conceptos, como en otras lenguas" (Arroyo 1966: 49). La ausencia de vocablos que codifiquen conceptos abstractos, una constante en la caracterización de los idiomas indígenas del país, mostraría, de acuerdo con este mismo eje ideológico, la pobreza semántica de estos:

No existe voz alguna con esta acepción [paz], como no se encuentran frecuentemente palabras que expresen abstracciones en ninguna de nuestras lenguas aborígenes. (1966: 191)

En términos generales -y especialmente en alusión al supuesto reducido caudal léxico de las lenguas amerindias-, podemos apreciar que se achaca la "pobreza" o "simplicidad" de estas al estado "primitivo" de desarrollo de las respectivas comunidades linguísticas, de modo que la ideología de la superioridad etnocultural se liga directamente con la ideología de la superioridad linguiística. Esta ideología es patente en Gagini (Pittier y Gagini 1892) y Arroyo (1966), pero también está implícita en gran parte de las descripciones de otros autores anteriores a la década de 1970:

\footnotetext{
Si se toma en consideración el estado primitivo en que viven aún los indígenas de Costa Rica, no causará extrañeza la pobreza de su diccionario. En efecto, un mismo vocablo sirve, á veces, con leves variantes de pronunciación, para designar ideas muy diversas, sin contar los casos en que el lenguaje translaticio hace innecesaria la creación de términos particulares, expresando con uno sólo todas las ideas semejantes.

Las palabras abstractas, por un fenómeno psicológico de clara explicación, escasean bastante en los pueblos incultos, quienes las reemplazan con circunloquios ú oraciones enteras [...]. (Pittier y Gagini 1892: 9)
}

Incluso ya bien entrada la segunda mitad del siglo XX, Arroyo reitera el lugar común de que estas lenguas han de contar con un repertorio léxico limitado, elemental y sencillo, a lo que le encuentra una explicación "racional" en la escasa sofisticación de la vida de los indígenas: 
Los diversos investigadores coinciden generalmente en que el léxico de nuestros idiomas indígenas es muy reducido. Esto es lógicamente explicable, desde luego que el lenguaje va íntimamente relacionado con la clase de vida de quienes lo hablan y es evidente que para expresar el pensamiento y las elementales relaciones de nuestros indios, es suficiente un vocabulario asimismo elemental y sencillo. (1966: 10)

Justo es destacar, no obstante, que en escritos de algunos autores (sin formación lingüística profesional) más recientes se explicita la creencia de que las lenguas amerindias no son inferiores o simples ni retratan un estadio de cultura poco desarrollado, sino todo lo contrario, como se aprecia en la siguiente explicación de Bernardo Drüg, recogida por Ramírez et al., acerca del bribri. Nótese que lo que sorprende a Drüg es la variedad léxica para codificar lo que al parecer son matices semánticos y, sobre todo, el sistema de parentesco tradicional bribri:

\footnotetext{
El año pasado saqué mucho rato para estudiar el idioma, y era apenas suficiente para darme cuenta de lo difícil que es. El idioma de esta gente no es como mucha gente se imagina, una lengua de salvajes, es una lengua de gente sofisticada.

Por ejemplo, nosotros decimos suave o suavecito; es casi la misma palabra. Ellos usan una palabra diferente para suave y otra para suavecito, o sea, ponen un adjetivo totalmente diferente. Eso se complica muchísimo.

Si el indio habla de su tío dice inmediatamente si es su tío materno o paterno. El oyente se da cuenta de cuál de los dos está hablando. Cuando está hablando del tío paterno, dice yë la, y cuando está hablando del tío materno, dice naùi; completamente diferente. Cuando se trata de la tía materna, dice amíla que quiere decir madrecita. Por eso el indio tiene a la tía materna un cariño muy grande, es como la segunda madre para él [...]. Ellos llaman hermano a cualquier pariente cercano. Por eso se dificulta el estudio del lenguaje. (1983: 38)
}

\subsubsection{Lenguas, dialectos y lenguajes}

Con base en la ideología de la jerarquía de los idiomas, el término "dialecto" se suele emplear popularmente para aludir a una variedad lingüística de rango inferior, menor complejidad o menor sofisticación intelectual en comparación con la categoría de "lengua" o "idioma". A este respecto, como anota Moreno, "se le da habitualmente un sentido peyorativo a dialecto $o$ variedad lingüística frente a lengua: lo primero se considera a veces más inculto, iletrado, variable, irregular y lo segundo se considera culto, letrado, constante y regular" (2006: 49).

En lo que se refiere a los escritos de naturaleza académica, desde finales del siglo XIX y hasta la fecha, predomina el empleo de las etiquetas "lengua" o "idioma" para aludir a las lenguas indocostarricenses (Pittier 1891, 1895, 1897, 1938, 1941; Schuller 1927a, b; Stone 1949, 1961; Arroyo 1966; Bozzoli 1969, 1986; Guevara y Bozzoli 2002; Guevara y Chacón 1992). Asimismo, es constante, aunque por lo general implícita, la distinción técnica entre "lengua" y "dialecto" (la segunda categoría entendida como variedad geográfica de una lengua) (Thiel 1882, Pittier 1897, Yglesias 1942, Arroyo 1966). No obstante, sobre todo en los textos anteriores a la segunda mitad del siglo XX, se encuentra también el empleo indiscriminado de ambas denominaciones (Pittier y Gagini 1892, Gagini 1917, Yglesias 1942), práctica que aparece esporádicamente aún en textos recientes (Acevedo 1986).

Así, por ejemplo, el uso indiscriminado de ambas etiquetas aparece en Gagini, aunque la categorización de estas lenguas como "dialectos" es mucho más frecuente en su caso. El segundo capítulo de su libro comienza del siguiente modo:

Es evidente que entre todos los dialectos que aún se hablan en Costa Rica existen afinidades más o menos aparentes, sobre todo en el vocabulario. Yo fui el primero que las encontré entre las lenguas de Talamanca y el Guatuso, considerado hasta entonces como lengua enteramente aparte [...]. Es lástima que por el momento sólo puedan hacerse comparaciones léxicas, pues hasta ahora hay únicamente dos estudios gramaticales sobre nuestros dialectos [...]. 
El ilustrado señor Obispo Thiel se limitó a recoger extensos vocabularios de los dialectos existentes sin dar mayor importancia a sus gramáticas, por medio de las cuales se puede establecer la filiación de las lenguas con más seguridad que basándose en simples semejanzas léxicas [...].

Los dialectos actuales de Costa rica pueden reducirse a cuatro tipos: $1^{\circ}$ EL TALAMANCA, comprendiendo bajo esta denominación el Bribri, el Cabécar, el Viceita y los dialectos de la Estrella, Chirripó, Tucurrique y Orosi. $2^{\circ}$ EL TERRABA (Térraba y Tiribi.) $3^{\circ}$ EL BORUCA o Brunca. $4^{\circ}$ EL GUATUSO.

Entre el primer grupo y el segundo hay bastantes analogías léxicas y gramaticales; el Boruca difiere sensiblemente de los dos anteriores; el Guatuso, si bien presenta algunas voces idénticas o muy semejantes a otras bribris, térrabas o borucas, es por fonología y su vocabulario el menos parecido a los dialectos del Sur.

$1^{\circ}$ EL TALAMANCA. - El vocabulario más antiguo que de este grupo poseemos es el de las lenguas Cabécar y Viceita hecho por los misioneros en el siglo XVIII [...]. (1917: 21-22)

En el caso de los viajeros, aparece también sistemáticamente el uso de la categoría "lengua" o "idioma" para aludir a las lenguas indocostarricenses (Kohkemper 1955), al lado de la etiqueta "lenguaje indígena" (Kohkemper 1955, Bovallius 1887 citado en Zeledón 1997), además de la distinción técnica entre ambos vocablos, que solo es relativamente explícita en la crónica de 1887 escrita por Bovallius:

Durante dos días continuamos nuestros estudios lingüísticos y enseñanza de la religión a los indios. Estos no se diferencian en nada en aspecto y en costumbres de los verdaderos indios Talamancas. Su lenguaje, en cambio, muestra algunas pequeñas diferencias pero no tan grandes que ambos no puedan ser considerados como dialectos del mismo idioma. (en Zeledón 1997: 150)

En los textos escolares de Estudios Sociales que mencionan, marginalmente, algún dato sobre la situación lingüística de Costa Rica, predomina la denominación de "lengua/ idioma” (Blen 2005, Cervantes 2005, Eduvisión 2008, Quirós 2005, Santamaría et al. 1994), pero no está ausente la de "dialecto" en el sentido de "código comunicativo de los indígenas" y no como "variedad de una lengua":

Las "reducciones" eran pueblos de indios a cargo de un sacerdote. Tenían varios dialectos, pero para leer la doctrina cristiana les enseñaron el español. (Quirós 2005b: 197)

Nuestros indígenas practicaban varios dialectos y tuvieron que aprender el castellano. Junto con este aprendizaje para comprender las sagradas escrituras, eran sometidos a reducciones y encomiendas. (Eduvisión 2008: 159)

En cuanto a los textos periodísticos, desde las noticias y reportajes más antiguos hasta los más recientes, ha aparecido comúnmente la denominación "dialecto" (La Nación 13/6/1963, 23/5/1971, 6/5/1976, 29/6/2000, 7/5/2009; Diario Extra 3/4/2007) y, en menor medida, la de "lenguaje" (LN 3/6/1973, LN 19/9/2009) para referirse a los idiomas indocostarricenses, si bien es usual que en las publicaciones de los últimos años predominen los vocablos "lengua" e "idioma". En lo concerniente a la lengua de señas costarricense (LESCO), debemos destacar que sigue predominando la etiqueta "lenguaje":

Entre ellos hablan el dialecto, el cual enseñan con sumo agrado a los visitantes. (La Nación 11/6/1963)

Este es el primer censo en el que se puntualiza sobre la población indígena en aspectos como el dialecto y el grupo étnico al que pertenecen. (La Nación 29/6/2000)

El lesco es el lenguaje de señas costarricense que permite comunicarse a quienes tienen problemas auditivos o dificultades serias para hablar.

Este lenguaje fue creado por la comunidad adulta del país que sufría de problemas auditivos. ( $L a$ Nación 29/4/2005)

En todo caso, justo es reconocer que no se encuentra ninguna valoración peyorativa explícita en los textos consultados. Cuando las instancias emisoras emplean la categoría de 
"dialecto" para referirse a las lenguas indígenas del país, parecen guiarse por un prejuicio simplemente asumido y nunca cuestionado, al estilo de la declaración de un joven profesional recogida en Sánchez: "los indios lo que hablan es un dialecto" (2013); o al estilo de la siguiente afirmación aparecida en un reportaje de La Nación: "Bien es sabido que los aborígenes hablan dialecto" (La Nación 23/5/1971). Es decir, aunque no quede muy clara la distinción entre "lengua" y "dialecto", lo cierto es que la segunda etiqueta se emplea solo para aludir a las lenguas indoamericanas, mientras que las lenguas europeas son denominadas siempre "idiomas" o "lenguas".

De esto se infiere que se considera que ha de existir alguna diferencia entre ambos grupos, lo que lleva a que se categoricen en clases distintas, y tal diferencia se basa, principalmente, en la comunidad de hablantes: los europeos hablan lenguas, mientras que los indoamericanos hablan dialectos. Opera, por lo tanto, la transferencia de prestigio $^{10}$.

En lo referente a la lengua de señas, sigue vigente la teoría de que las lenguas deben materializarse por medio de un canal oral-auditivo, de modo que si se emplea un canal visual-gestual se concibe que son códigos comunicativos, pero no idiomas. Ello explica que se sigan denominando "lenguaje". En el fondo, probablemente opera en este caso también la transferencia de prestigio: las personas sordas son conceptualizadas como discapacitados, y como las lenguas de señas son idiomas "creados" y empleados predominantemente en la comunicación entre personas sordas, entonces han de ser algo menos que una lengua (un mero movimiento de manos, por ejemplo).

\subsubsection{La ideología de la relación entre lengua y capacidades cognitivo-intelectuales}

Otra faceta de la ideología de la superioridad étnico-racial y su dimensión lingüística (la ideología de la superioridad de unas lenguas frente a otras) que encontramos en las fuentes escritas está relacionada con las capacidades cognitivo-intelectuales de los individuos y el vínculo que supuestamente existiría entre estas y la lengua materna, el dominio del español y la alfabetización.

En primer lugar, conviene hacer notar la convicción de que existirían "indios" más o menos inteligentes que otros, con la insinuación pareja de que la inteligencia se vincula con la aculturación (“civilización"), creencia patente en los textos de Gabb $(1875,1883)$ y Pittier (1897). En otros documentos, destaca no la consideración de que existen diferencias cognitivo-intelectuales individuales, sino que estas se originan en el grupo de pertenencia del individuo. Es decir, en algunas fuentes se explicita la creencia de que unos grupos indígenas son más inteligentes que otros. En Stone, son los cabécares los que superan a los bribris:

\footnotetext{
La mayoría de los lingüistas entroncan las lenguas bribri y cabécar con la chibcha. Sin embargo, estas se hallan suficientemente separadas entre sí para que no puedan operarse mutuos intercambios. Los más avanzados intelectualmente, pero al mismo tiempo los conquistados cabécares, en general entienden y hablan bribri [...]. (1961: 20)
}

En Pittier, son los borucas quienes aventajan a todos los demás, lo cual es motivo de sorpresa para este autor en vista de que su sistema numeral contempla pocos elementos y al parecer él hubiera esperado que la mayor intelectualidad y civilización de los borucas se correlacionara con un sistema numeral más desarrollado:

The Brunka Indians certainly do not count beyond eight, and this is much the more to be wondered at, inasmuch as they are by far the most intellectual and civilized of all the Costa Rica Rican aborigines. (1904: 454) 
Asimismo, en el discurso de este mismo autor, se explicita inclusive una conexión entre variación lingüística, psicología y conducta en el caso de los bribris:

\begin{abstract}
En Talamanca hay por lo menos tres dialectos distintos, a saber: el de Lari, el de Uren y el de Coen. Estos dialectos difieren muy poco, pero permiten de reconocer inmediatamente la procedencia de un bribrí por su modo de hablar. Así, por ejemplo, la gente de Lari (Ararí) que es, o era en mi tiempo, la raza más fuerte y más enérgica, reflejaba su fuerza en su habla, más rápida y con entonaciones más acentuadas. Así es que, por no citar más que un caso, la consonante $l$ casi no existe en su vocabulario, mientras la $r$ ocurre a menudo. Entre la gente de Coen, más floja y poco activa, sucede lo contrario y la $l$ repone la $r$. (1941: 6)
\end{abstract}

En segundo lugar, la ideología de la jerarquía étnico-cultural, en la que se fundamenta la jerarquía lingüística, se manifiesta también en la creencia de que existen grados de "primitivismo" y desarrollo idiomático en las propias "tribus incivilizadas". Esta teoría lingüística se halla, tácita o explícita, en autores como Pittier (1904) y Gabb (1895).

Por ejemplo, de lo expresado en Pittier se infiere que existe una especie de escala de desarrollo de los sistemas lingüísticos, el cual se manifiesta al menos en los sistemas numerales, en los cuales se establecen subsistemas de números para contar dependiendo de la clase a la que pertenece el elemento contado (esto es, en varias lenguas existen diferencias en la forma lingüística de los números para contar, por ejemplo, objetos redondos, objetos alargados, personas, etc.):

\begin{abstract}
It is not for me to decide whether the variation according to the class of the objects to be counted, observed in the numerals of several of the languages referred to in this paper, is a peculiar and original feature of these languages, of whether it has been transmitted form a more highly developed linguistic system. (1904: 457)
\end{abstract}

En tercer lugar, al cambiar el parámetro de comparación, la ideología de la superioridad étnico-cultural hace que los autores expliciten proposiciones en las que los europeos y -por transferencia de prestigio- sus atributos culturales son juzgados como "más civilizados" (o simplemente como "civilizados") que los indígenas costarricenses y los atributos propios de sus culturas tradicionales (Gabb 1875, 1883; Pittier 1897; von Frantzius 1925; Yglesias 1942; Kohkemper 1955).

Esta presunta diferencia en el grado de civilización puede tener una manifestación lingüística. En el caso de von Frantzius, por ejemplo, se establece un ligamen explícito entre “civilización” (es decir, "europeización”) y linguodiversidad:

Aunque son distintas las lenguas de las diversas tribus aisladas, caso más frecuente en pueblos de tan ínfimo nivel de civilización que en los cultos, la constitución física, los usos y costumbres de estos aborígenes tienen tal conformidad, que debemos considerar como pertenecientes a una gran raza o tronco, todos los de las tribus que vivieron y viven aún en la parte del nordeste de Centro América, desde Honduras hasta la laguna de Chiriquí, llamados Poyais, Toacas, Coocras (Cocoras), Woolwas y Ramas, lo mismo que los del territorio de Costa Rica, denominados Guatusos, Viceitas, junto con los Valientes. (1925: 233)

En todo caso, este eje ideológico de la conexión entre intelectualidad y lenguaje es mucho menos frecuente y menos elaborado que el tratado en el subapartado anterior. Aparece, sobre todo, en los autores de finales del siglo XIX, cuando comentan sobre las vicisitudes que tuvieron que enfrentar y las ayudas que recibieron, de parte de sus hablantes, para estudiar las lenguas indocostarricenses. Al parecer, algunos daban por sentada la existencia de una correlación entre inteligencia, aculturación y manejo del idioma español. Al menos eso se puede inferir de lo que anota Gabb $(1875,1883)$ : 
He tenido la ventaja no solamente de vivir año y medio en el país, en contacto diario con un compatriota, que habla la lengua [bribri] corrientemente y que me puso por lo mismo en aptitud de aprenderla; sino que también, mientras tanto, estándo ausente, durante dos meses tuve en mi compañía varios indios inteligentes que entendían el castellano. (1883: 389)

En el caso de Pittier, al parecer la correlación se establecía más bien entre desarrollo intelectual y alfabetización en español:

\begin{abstract}
La formación del glosario guatuso ofrece incontestablemente más dificultades que la de cualquiera de los demás idiomas hablados todavía en Costa Rica, exceptuando talvez al térribe. En Térraba y Boruca, varios indios leen y escriben la lengua castellana, lo que presupone un desarrollo intelectual relativamente considerable. (1897: 10)
\end{abstract}

En cualquier caso, es claro que se manifiesta una y otra vez la ideología que vincula la "calidad lingüística", la etnicidad y la raza (en su sentido fenotípico-genético tradicional, con toda la carga ideológica que históricamente ha implicado el término). Al respecto, en nuestros escasísimos datos acerca del inglés criollo limonense, hallamos una proposición ideológica marcadamente prejuiciada en la que se expresa el "saber común" de que los afrodescendientes ("los negros") no hablan bien ni español ni inglés, y que incluso "han deformado" los topónimos de origen indígena de la región de Talamanca:

\begin{abstract}
Es importante llamar la atención del lector en este punto, para que se ponga en guardia contra la autenticidad de los nombres geográficos de Talamanca, que sus habitantes alteran constantemente. Esto obedece en mi opinión a dos causas: a la variedad de dialectos indios que denominaron un mismo lugar de manera distinta aunque parecida, y a la presencia de los negros que bien sabemos que pronuncian mal el inglés y el castellano, deformando también de consiguiente, los nombres indígenas. (Kohkemper 1955: 83)
\end{abstract}

\title{
4.1.3. La ideología de la conexión entre variación idiomática y escritura
}

En nuestro corpus, la creencia de que las lenguas normalmente son sistemas homogéneos o estables está ligada al complejo ideológico de la superioridad idiomática, lo que lleva a algunos intelectuales a opinar que la variación de los idiomas indocostarricenses se debe a su primitivismo, a ser ágrafos o a no contar con literatura (en el sentido de textos escritos), con lo cual se obvia que los idiomas europeos también presentan una gran variación en todos sus niveles y en todos los territorios donde se han extendido.

Sin duda, la ideología de la superioridad lingüística es el trasfondo de la teoría según la cual las verdaderas lenguas, las lenguas "civilizadas" o "cultas", se escriben. Al respecto, en el ámbito costarricense, Wilson comenta acerca de un debate universitario en época relativamente reciente en el que el punto álgido consistía en decidir si las lenguas indocostarricenses, ágrafas y sin literatura escrita, podían ser consideradas "lenguas":

Hasta hace pocos años en Costa Rica no se escribía ninguna de las lenguas indígenas. Este hecho dio pie a situaciones cómicas debido a la creencia general de que si una lengua no se escribe no es lengua sino "dialecto". Cuando en la Universidad de Costa Rica se estaba organizando el primer Departamento de Lenguas Modernas, hubo una larga discusión sobre si el nuevo departamento podría incluir en su currículum el estudio de las lenguas indígenas. En cierto momento, una mayoría de profesores opinó que no, porque al no poseer alfabetos lógicamente no tenían "literatura", y sin literatura los indígenas no poseían lenguas. Hablaban "dialectos" y estos no tenían cabida en un departamento de "lenguas". (1996: 39-41)

En esta misma tónica, los fenómenos de variación diatópica y diastrática son valorados por diversos autores como rasgos propios de la categoría a la que pertenecen las lenguas indocostarricenses (tácitamente, se reconoce como un tipo de lenguas inferior). La teoría 
consiste, en esencia, en una especie de explicación de la variación: el idioma varía y cambia precisamente porque esa es la naturaleza de los idiomas ágrafos (Gabb 1875, 1883; Pittier y Gagini 1892; Pittier 1941).

La relación entre falta de escritura y propensión al cambio es expuesta con detalle por Gabb $(1875,1883)$, en relación con las lenguas talamanqueñas, en el siguiente párrafo. Nótese cómo la motivación del cambio lingüístico no se busca en la escisión del grupo y el desplazamiento de una parte de este a un territorio distante, con el consecuente cese de comunicación entre los subgrupos (como ocurrió en el caso de la separación entre el térraba y el tiribí o teribe) ni tampoco se especula en torno a la relación entre divisiones geográficas y variación idiomática (como sucede en bribri). Al final del párrafo, Gabb suscribe otra explicación adicional: la "pereza" articulatoria como detonante de la variación:

\begin{abstract}
No cabe la menor duda que éste [el idioma bribri] y los dialectos afines, así como todas las lenguas no escritas, están sufriendo grandes cambios. La lengua que se habla en Térraba era antes, y probablemente no ha mucho tiempo, la misma de Tiribí. Marcadas son las diferencias entre la de Cabécar de Coén y la de la Estrella ó North-River, y aun diferencias locales en el uso de la $r, l$ y $d$, pueden observarse entre la mitad de la tribu Bribri que vive en el Urén, y las demás esparcidas en el resto del país. En varios distritos "un poco", wi-ri-rí-ri, lo pronuncian también bi-ri-bí-ri y wi-di-wí-di; y muchas otras palabras, especialmente las que llevan $r$ ó $d$ antes de una vocal, varían del mismo modo. Como observa Max Müller, con mucha justicia, la pereza contribuye con frecuencia á esto. El nombre actual de la lluvia kón-ni, por ejemplo, se deriva claramente de kóng-li. En efecto, existe la prueba de ello en la forma de la palabra polvo, kóngmo-li. Pero kón-ni es mas fácil de pronunciar que kóng-li, y la ha sustituido. (1883: 390)
\end{abstract}

El mismo nexo causal entre carencia de un sistema gráfico de representación del idioma y variación fonológica es expuesto por Gagini (Pittier y Gagini 1892) con respecto al térraba, pero en este caso se llega a afirmar incluso que la variación es individual y hasta caprichosa (se debe a "la fantasía" del que pronuncia una palabra). Reaparece al final una declaración explícita de la categoría idiomática a la que pertenecería el térraba ("el habla de tribus salvajes"), lo que da una pista de que, en el fondo, se establece un ligamen entre primitivismo, agraficidad de la lengua y variación fonológica:

Confunden frecuentemente los térrabas los sonidas [sic] $f$ y $p$, pronunciando v.gr.: pon ó fon (nube); la $r$ y

la $l$, como en dri ó delí (alimento); la $k$ y la $g$, como se observa en kro ó gro; la o y la $u$, etc.

Adviértase también, como en todas las lenguas que carecen de escritura, variantes en la pronunciación de un mismo vocablo, metaplasmos que dependen del uso que de él se hace, del lugar que ocupa en la proposición ó de la fantasía del que lo pronuncia, observación que puede comprobarse preguntando á varios indígenas el nombre de una cosa y haciendo que lo empleen en diversas frases.

Es éste uno de los principales escollos con que tropiezan los que estudian el habla de tribus salvajes, y lo que motiva las diferencias ortográficas, más aparentes que reales, de los vocabularios impresos. (1892: 8-9)

Los mismos vínculos entre agraficidad, variación lingüística interindividual y propensión al cambio aparecen en Pittier en alusión al bribri y al brunca, esta vez mediante la expresión explícita de las proposiciones ideológicas respectivas ("los idiomas no escritos varían de un individuo a otro", "los idiomas no escritos evolucionan incesantemente"):

Los idiomas no escritos varían de un individuo a otro. Esto lo había notado ya en Talamanca, pero esta dificultad se hizo más patente en mis vanos esfuerzos para dominar el brunka. El mismo recuento, dicho por dos personas y en fechas separadas, difería sensiblemente y constantemente aparecían modos distintos de expresar la misma cosa. Pero cualquier dicción era entendida sin dificultad por la generalidad de los brunka. [...] Asímismo, los idiomas no escritos evolucionan incensantemente [sic]; las expresiones y palabras cambian, y al contacto con otro lenguaje muchas se pierden y son respuestas por "barbarismos". Estoy seguro que el bribrí y el brunka de hoy no son ya exactamente iguales a los que estudié en los años de 1890-1900. (1941: 6) 


\subsection{El complejo ideológico de la relación entre lengua e identidad}

En nuestro corpus, el vínculo entre identidad étnica y lengua vernácula, así como entre identidad nacional y lengua nacional, constituye el segundo complejo ideológico más relevante. Es, además, el que muestra más continuidad en las fuentes escritas y el que suele aparecer en los textos académicos contemporáneos, sobre todo en los de índole antropológica. Finalmente, está presente en los textos periodísticos y escolares también. Esto muestra que la conexión entre lenguaje e identidad grupal constituye un eje ideológico que ha tomado más fuerza con el tiempo y que su conceptualización, al resultar menos "técnica" que la de la jerarquía y la naturaleza de las lenguas, permite que sea un tema al que puede aludirse, sin mucha elaboración, en cualquier tipo de texto.

Desde el enfoque esencialista de la identidad -que es el que prima en nuestro corpus-, se parte de que esta es un atributo natural e inmutable de las personas, no una construcción psicosocial. De este modo, por ejemplo, sobresale la creencia de que las personas pertenecen a comunidades étnicas fijas por naturaleza y que tales comunidades se definen a partir de parámetros "tangibles" como la lengua.

\subsubsection{La ideología de la lengua como índice de identidad}

Desde hace décadas, en el discurso académico costarricense se viene asumiendo sin cuestionamiento que existe un relación "natural" (o esencial, si se quiere) entre adscripción étnica y lenguaje. Esto explica por qué se ha tomado el dato de hablar la lengua vernácula como índice de identidad étnica en los trabajos de corte antropológico. Así, por ejemplo, en Bozzoli y Wing-Chang, el parámetro para reconocer la pertenencia de las personas a un grupo indígena es el ser hablante de la lengua vernácula de ese grupo (térraba, boruca, bribri, cabécar, solo español):

\footnotetext{
Como Buenos Aires es, en el Pacífico Sur, el cantón con mayor número de habitantes de origen indígena, y como en el área a desubicar se encontraban ciudadanos de este origen, se consideró conveniente determinar su porcentaje y algunas características, dado que se pretende tomar en cuenta las diferencias culturales en cuanto éstas pueden influir en los cambios que se proyectan [...]. En el interés de favorecer tanto a la etnia "indígena" como a la etnia "blanca" se solicitaron los datos de base que a continuación se exponen.

“Además del español, qué otro (s) idioma (s) se hablaban en la casa?” [...]. Las preguntas sobre idioma se utilizaron como el indicador de la etnia. (1979: 171)
}

En esta línea de pensamiento, si la lengua vernácula y otros componentes de la sustancia cultural tradicional de un grupo han sido desplazados por completo, se asume que la diferenciación étnica ha perdido vigencia y tal grupo no es "verdaderamente indígena", como se aprecia en las siguientes palabras de Guido Barrientos, quien fue asesor del Ministerio de Educación Pública en la región sur del país:

\footnotetext{
[L]os verdaderos grupos indígenas que queda actualmente son los bribris, cabécares, guaymíes, borucas, térrabas y malekus. Yo excluyo a los chorotegas y huetares porque han perdido hasta su propio idioma. Los huetares de Quitirrisí sólo conservan de su cultura el tipo de rancho, los rasgos físicos y la artesanía. Cuando visité a los Chorotegas en Matambú, sólo encontré uno que otro vestigio de su cultura, pero ellos han perdido su propia lengua y han olvidado gran parte de su cultura. Ahora son como cualquier otro campesino. (1993: 10)
}

En particular, en el discurso académico antropológico, el ligamen entre lengua vernácula e identidad étnica se explicita en referencia con el tema que viene destacándose 
desde finales del siglo XIX: la aculturación de los distintos grupos indocostarricenses y la pérdida correlativa de los componentes tradicionales de su especificidad histórico-cultural como grupos distintos a las etnias europeas y a la hispanocostarricense. En Guevara y Chacón, por ejemplo, este ligamen es patente:

\footnotetext{
Los Borucas son el único pueblo originalmente situado en la región sur de Costa Rica que logró sobrevivir a la conquista y a la colonia conservando su identidad cultural, y a pesar de los efectos de la dominación española. Sin embargo han sido sometidos a procesos intensos de aculturación desde mediados del siglo $\mathrm{XX}$ al punto de haber prácticamente perdido rasgos fundamentales de su identidad como el idioma, el cual solo es dominado hoy por dos o tres hablantes. (1992: 19)
}

De hecho, es común que se asocie la pérdida de la lengua vernácula con la pérdida de la identidad étnica, y que, por el contrario, se ligue el orgullo por la adscripción étnica diferenciada a la hispanocostarricense con el mantenimiento del idioma autóctono, de modo que se maneja implícita o explícitamente una teoría sobre el desplazamiento o conservación de las lenguas: a mayor orgullo o conservación de la identidad étnica, mayor vitalidad de la lengua vernácula:

\footnotetext{
A pesar del asedio tan impresionante del que ha sido objeto esta población desde hace poco más de un siglo, al punto de constituirse, prácticamente, en una población proletarizada, sorprende la capacidad de los Malekus por aferrarse a su cultura y el orgullo que manifiestan con respecto a su identidad originaria. Para 1967, todos los indios hablaban su lengua materna, e incluso los niños menores de 5 años (no escolarizados) desconocían aún el español [...]. (Guevara y Chacón 1992: 104-105)
}

En este complejo de conexiones, también ha sido constante en el discurso académico oponer el mantenimiento de las lenguas vernáculas a la adaptación a la vida "moderna" por parte de las comunidades indocostarricenses, de modo que tácitamente se establece una dicotomía entre tradición y modernidad, en la que "vida moderna" se entiende básicamente como "cultura occidental contemporánea":

\footnotetext{
Nuestro indio diezmado y miserable, casi carente de tradición, de música propia, de arte y escaso de folklore, cada día se adapta más a la vida moderna, olvidando sus tradiciones y lenguas. Los indios jóvenes y los niños, por ejemplo, no quieren aprender su lengua materna, a la que miran hasta con vergüenza, por un complejo psicológico explicable en una raza vencida por el conquistador primero, y humillada después hasta nuestros días por abusos y arbitrariedades vergonzosas. (Arroyo 1966: 16)
}

Esta misma asociación ideológica entre adaptación a la modernidad y abandono de las lenguas vernáculas, así como la creencia de la incompatibilidad entre la vida "moderna", la tecnología y la conservación de la identidad étnica diferenciada y de los componentes de la sustancia cultural tradicional, aparecen también en los textos periodísticos de los últimos años:

\footnotetext{
Aprender a usar computadoras e Internet, comunicarse en inglés y pasar la escuela con buenas calificaciones; esas son las aspiraciones de los niños y jóvenes de Suretka. Desgraciadamente, hablar bribri ya no es una de ellas. (La Nación 18/11/2007)
}

\subsubsection{La ideología del idioma nacional como el natural y esperable}

Desde que se implanta el sistema colonial español, no solo la configuración política del continente americano va a cambiar radicalmente, sino que también va a reestructurarse la categorización de los grupos humanos. Así, surge el "indio" ("indígena", "aborigen", "amerindio", "indocostarricense" y demás pan-etnónimos que se han acuñado desde hace más de cinco siglos), macrocategoría étnica inventada e impuesta por los conquistadores europeos como 
etiqueta homogeneizadora con la que se desdibujaron y ocultaron las particularidades de cada grupo y se estableció una oposición global entre los nativos americanos que no eran de origen europeo y los conquistadores o sus descendientes (incluyendo a los mestizos) (Mires 1991).

Posteriormente, con los movimientos independentistas de la primera mitad del siglo $\mathrm{XIX}$, se reestructuraron de nuevo los territorios y, como corolario, se configuraron nuevas identidades colectivas, fundamentadas esta vez en la pertenencia a un territorio separado en los niveles político, administrativo y económico de los territorios adyacentes. Operan aquí, entonces, los mecanismos ideológicos de conformación de las "identidades nacionales", pues se siente la necesidad de construir una separación cultural también, de modo que se escogen determinados atributos, tradiciones y elementos materiales como representativos de la diferencia nacional.

Los grupos indígenas, considerados, en un primer momento, como excluidos de esta nueva nación debido a su especificidad étnico-cultural diferenciada, serán luego incluidos y hasta considerados los costarricenses "verdaderos" u "originarios". Por ello, la ideología nacionalista hegemónica constantemente apelará a la necesidad de, en palabras de Yglesias, "incorporarlos a la vida nacional":

[A]ún cuando es cierto que los grupos de aborígenes que subsisten no han influído en la vida económica, política y social del país, es lamentable el abandono en que se les ha tenido, siendo hora ya de dictar las medidas necesarias para promover el mejoramiento de las precarias condiciones en que se encuentran, para incorporarlos a la vida nacional. (1942: 10)

En este contexto, se implanta una ideología lingüística altamente difundida a partir del expansionismo europeo, surgida y afianzada con fuerza en el Viejo Continente desde antiguo: la ideología de la relación intrínseca entre Estado, nación y lengua nacional, de acuerdo con la cual a cada Estado nacional o país le corresponde un idioma nacional. Así, se institucionaliza la creencia de que debe existir una lengua común y que, en el caso de Hispanoamérica, esta debe ser el español, de modo que se concibe que lo natural y conveniente es que todos los habitantes de un mismo país dominen la lengua nacional, pues es este el atributo lingüístico intrínseco a la nacionalidad costarricense, por ejemplo.

Este razonamiento explica la preocupación expresada por la Junta de Protección de las Razas Aborígenes de la Nación en 1920, en cuanto a que los grupos indocostarricenses aprendieran español con el fin de formar parte de la nación y ser capaces de comunicarse con los demás individuos que la conforman:

\footnotetext{
Al mismo tiempo, todo hombre es parte de la sociedad humana y, por lo tanto, es necesario que se forme y desenvuelva para ser útil dentro de ese gran conjunto; para conseguirlo necesita comunicarse y entenderse con la mayoría de los hombres que lo rodean; y siendo el idioma nacional de Costa Rica el castellano, la Junta considera también de suma importancia la enseñanza de dicha lengua a cada uno de los ciudadanos; y por ello se propone enseñar todos los núcleos de la población indígena a hablar, escribir y leer el castellano. (citado en Pozas 1920: 2)
}

Este eje ideológico está ausente en el discurso académico, pero aparece en los textos periodísticos de entre 1950 y 1970 que tocan el tema linguiístico. Ante todo, la reacción del periodista es de sorpresa al constatar que existen "genuinos" costarricenses que no hablan español. Esta emoción solo puede comprenderse si se tiene presente la expectativa de la instancia emisora en lo relativo a que todo miembro de la nación costarricense ha de dominar el idioma nacional: 
Fué en Moravia donde tuvimos el primer contacto con la vida indígena. Conversamos -si así puede decirse- con dos indios que venían a vender sus productos. Uno de ellos hablaba un español primitivo y el otro sólo su lengua indígena.

Produce una sensación extraña encontrarse por primera vez con un genuino "costarricense" con el que hay que entenderse por señas por hablar otro idioma. Pero esta fué una experiencia que había de sucedernos a menudo. (La Nación 8/3/1953)

Un porcentaje alto de los estudiantes son indígenas. Problemas de adaptación o de lenguaje? Ninguno, contesta el director. Estudian y se adaptan igual que los otros. Bien es sabido que los aborígenes hablan dialecto; que muchos, aunque parezca mentira, ya que no tenemos más de cuatro mil indios en todo el país, no hablan español. (La Nación 23/5/1971)

El mejor ejemplo de expresión de esta ideología se encuentra en el artículo "Ticos auténticos...que no hablan español”, publicado en La Nación el 2 de abril de 1970. En él, constantemente se repite la estupefacción del autor de que haya costarricenses que desconozcan la lengua nacional, con todos los problemas que ello conlleva para comunicarse con los representantes de las instituciones nacionales. Tanto el titular como con mayor explicitud la leyenda "Auténticos ticos...y sin embargo muchos de ellos no hablan español" -que aparece al pie de una fotografía ilustrativa- revelan que lo esperable, según la instancia emisora, es la ecuación "ser costarricense" = "hablar español":

\footnotetext{
Los talamancas aún conservan sus lenguas nativas. Cada grupo habla su propio dialecto. Y no se entienden individuos de tribus diferentes, a menos que recurran al español o en casos muy especiales. Bribris, cabécares, chirripóes, etc., hablan sus dialectos heredados de milenios. Hoy día, aunque parezca increíble, se da el caso de que muchos de estos auténticos costarricenses, los más auténticos, no hablan español. Para el médico, el cura o el maestro esto resulta un verdadero obstáculo, pues es difícil entablar la comunicación. Las antiquísimas voces de sibú, quebe, cedova, siuo, sustituyen las castellanas de Dios, culebra, muerte y luna. (La Nación 2/4/1970)
}

La consternación por los problemas de comunicación provocados por el monolingüismo en el idioma indocostarricense respectivo aparecerá en otros textos, en los que nunca se cuestiona por qué el maestro foráneo no intenta aprender la lengua vernácula de sus estudiantes. En términos técnicos, diríamos que siempre se espera, con base en el eje que estamos comentando, que la convergencia lingüística se produzca de parte del indígena hacia el hispano y nunca al revés. Además, el fracaso escolar se concibe, más que como un problema lingüístico y de choque cultural, como un problema cognitivo. Así se consigna en un artículo de 1970 sobre una visita a Amubri:

\footnotetext{
La influencia de la escuela se nota rápidamente en estas apartadas regiones. Muchos vecinos saben leer y escribir. Pero en lo que "se echa de ver" principalmente es en el trato. No son huraños; sonríen, saludan invariablemente con un "buenos días o buenas tardes", y en general resultan asequibles. Cómo trabajan los maestros? ¿Es el idioma un problema? ¿Aprende con facilidad el indio? La hermana Luz Berta nos contesta: "El idioma, desde luego, es un gran obstáculo en el aprendizaje. Hay mucho niño que habla sólo el dialecto y unas palabras del español. Tenemos, pues, que empezar por enseñarles a hablar. Por otra parte, les cuesta un poco el estudio. Casi todos tienen que repetir el primer grado. (La Nación 9/4/1970)
}

Esta asociación entre fracaso escolar y escaso dominio de la lengua nacional (y de instrucción) también es patente en lo consignado en las actas de los cuatro Seminarios de las Escuelas Indígenas celebrados en 1953. Por ejemplo, en el acta del cuarto seminario, realizado en Salitre, se aprecia con facilidad que los idiomas vernáculos, y especialmente el monolingüismo infantil en ellos, se conciben como barreras para alcanzar los propósitos pedagógicos, debido a que los niños entran a la escuela "hablando dialecto" (problema lingüístico) y "pensando en dialecto" (problema cognitivo): 


\begin{abstract}
Don Tito Acosta nos habla sobre Metodología de la Composición en todos los grados de la Escuela Primaria. Hizo interesantes recomendaciones basadas en su larga práctica como maestro de las Escuelas Indígenas. "En el primero y segundo grados -dijo don Tito- el asunto es más delicado tratándose de alumnos indígenas, que llegan hablando dialecto y pensando en dialecto y a veces ni en dialecto." Recordemos -agregó el señor Acosta Corella- que en dialecto no hay artículo, número ni género; hay escasas palabras de relación y además ellos tienen construcciones diferentes. (en Acosta 1953: 359).
\end{abstract}

Por lo demás, nótese cómo en el párrafo citado se infiere que las diferencias tipológicas entre las lenguas indocostarricenses y el español ("en dialecto no hay artículo, número ni género; hay escasas palabras de relación" y "construcciones diferentes") provocan mayores problemas de composición en los estudiantes indígenas. Con ello, se obvia que se está imponiendo un sistema educativo (occidentalizante) ajeno a la cultura tradicional, implementado en una lengua que resulta extraña a los niños y a su entorno comunicativo cotidiano.

$\mathrm{Si}$ bien se concibe entonces que toda persona que viva en el Estado denominado "Costa Rica" debe, naturalmente, hablar español, ya que se trata de la lengua nacional, la actitud no deja de ser un tanto ambigua, puesto que la ideología en boga en los últimos años plantea que los pueblos indígenas, al descender de las poblaciones originarias del territorio, son los "verdaderos" o "auténticos" costarricenses, de modo que sus prácticas culturales son también las más auténticas y, por lo tanto, conforman la identidad "original" del costarricense. Esta creencia se expresa con total explicitud en las siguientes palabras de Guido Zamora Barrientos, supervisor de educación en Talamanca:

\begin{abstract}
Hay un total de tres mil costarricenses autóctonos que hablan el bribri. Es nuestra lengua original, porque el español es una lengua foránea; la lengua del conquistador. En cambio, el bribri es una lengua autóctona, nuestra. Es muy importante que nosotros vayamos a buscar las raíces culturales nuestras, que conozcamos nuestra realidad, incluso la lengua. (en Rodríguez et al. 1983: 119)
\end{abstract}

\title{
5. Algunas tendencias en cuanto a períodos e instancias emisoras de las ideologías
}

La expresión de ideologías lingüísticas valorativas con respecto a las lenguas indocostarricenses es común en los autores de textos académicos de finales del siglo XIX (todos ellos extranjeros) y de la primera mitad del siglo XX que se ocuparon de recoger materiales (predominantemente listados léxicos y unos pocos textos narrativos y cantos) y de llevar a cabo someras descripciones de la gramática y de la fonología de estos idiomas.

Conforme se "profesionalizaron" los estudios linguiísticos, la explicitación de tales ideologías se ha reducido drásticamente en este tipo de discurso, lo cual concuerda en gran medida con las periodizaciones establecidas por Quesada Pacheco (1992) para el español y por Constenla (2004) para las lenguas de la Baja Centroamérica con base en el parámetro de sustentarse los trabajos lingüísticos en teorías científico-descriptivas contemporáneas.

Sin embargo, no debe pensarse que a partir de 1970 entramos en una época de ausencia total de ideologías linguíísticas. Lo que ocurre es que, en primer lugar, el criterio de "objetividad" -canónico en la ciencia contemporánea- preponderará en las descripciones, lo que implicará que los autores se inhiban de expresar abiertamente sus gustos y percepciones subjetivas acerca de las lenguas -si es que las tienen- y se limiten a inventariar los repertorios fonológicos, léxicos y gramaticales -en el caso de quienes se adscriben a las corrientes estructuralistas descriptivistas-, o a verificar hipótesis y replicar metodologías con el fin de poner a prueba o aplicar teorías lingüísticas generales -en el caso de quienes han seguido las corrientes generativistas y funcionalistas, entre otras (ver Sánchez 2013 para un recuento al respecto)-. 
En este sentido, las ideologías lingüísticas que se manifiestan con mayor claridad son aquellas que las mismas corrientes seguidas proponen como axiomas, hipótesis, supuestos teóricos o métodos de trabajo. Por ejemplo, entre 1970 y 1980 se elaboraron varias tesis de grado de corte generativista chomskiano (v.g. Álvarez et al. 1979, Campomanes 1980, Castro et al. 1979, Díaz et al. 1976). En estas, los proponentes trabajaron con la siguiente metodología: primero elaboraron listas de oraciones en español; luego estas fueron traducidas por un hablante nativo de la lengua investigada; y finalmente los autores se dedicaron a describir la estructura superficial de tales oraciones, a "reconstruir" la estructura profunda que subyacía a las manifestaciones gramaticales superficiales y a elaborar las reglas transformacionales que darían cuenta de las peculiaridades sintácticas del idioma descrito en relación con los supuestos de base de la teoría en cuanto a la forma de la gramática universal.

Como se puede apreciar, se encuentra todo un planteamiento ideológico "profesional" en este proceder: el componente sintáctico es más importante que los demás; la descripción de la forma de oraciones aisladas y descontextualizadas permite descubrir la estructura de la lengua; la función del lenguaje que importa es exclusivamente la referencial; se puede conocer la estructura de la lengua por medio del estudio del habla de un solo individuo, pues se supone que este es un hablante ideal; existe una estructura profunda universal de las lenguas y lo que no calza con lo predicho por la teoría es considerado transformaciones idiosincráticas; la lengua se estudia como objeto autónomo sin prácticamente ninguna referencia a la comunidad lingüística respectiva (por ejemplo, a su cultura y hábitat).

El mismo tipo de caracterización de los párrafos anteriores podríamos llevarlo a cabo con los estudios basados en las otras corrientes lingüísticas. Sin embargo, este no ha sido el interés de nuestra exposición, pues lo que deseábamos era proponer un esbozo del tipo de ideologías lingüísticas más relacionado con lo que se ha llamado "prejuicios lingüísticos" (Tusón 2010), "mitos del lenguaje" (Bauer y Trudgill 1998), "teorías populares acerca del lenguaje" (Niedzielski y Preston 2003) y "actitudes lingüísticas" (Baker 1992). Llevar a cabo un análisis de los supuestos teóricos de base de los estudios descriptivos acerca de las lenguas costarricenses a partir de 1970 nos llevaría a formular una historiografía propiamente lingüística, más que una historiografía de las ideologías lingüísticas, y ello se escapa a los objetivos del presente trabajo.

En cuanto a las otras fuentes escritas de las que proviene el corpus que hemos analizado, cabe destacar la exigüidad y poco detalle de las manifestaciones discursivas de las ideologías lingüísticas. Más en general, cabe subrayar que en realidad el tema de la diversidad lingüística y de las lenguas minoritarias de Costa Rica ha sido de poco interés para las instancias emisoras del discurso periodístico y de los textos escolares de las asignaturas de Español y de Estudios Sociales.

Así, en los textos periodísticos predominan las noticias relativas a los problemas socioeconómicos de los pueblos indocostarricenses (desplazamiento y luchas por recuperar sus territorios, condiciones de sanidad, producción agrícola, educación), así como las noticias concernientes a la manifestación, conservación y pérdida de las culturas tradicionales. Es en especial cuando se trata esta segunda temática cuando aparece la cuestión lingüística, casi siempre de modo tangencial, a no ser que la noticia gire en torno al fenómeno mundial de la muerte de lenguas y a su expresión en el contexto costarricense.

Aun así, es posible reconocer, preliminarmente, dos etapas en el tratamiento de los temas idiomáticos. En una primera época (que iría de 1940 a más o menos 1970), sorprende que existan indígenas que no hablen español, hecho inconcebible desde el prisma de la 
ideología de acuerdo con la cual a todo Estado corresponde una lengua común. En una segunda etapa (más o menos a partir de 1980 y hasta el presente), se aprecia el interés por levantar la voz de alerta con respecto a la desaparición de las lenguas indocostarricenses.

En los textos escolares, por su parte, las lenguas indocostarricenses solo se mencionan de paso cuando se describe sucintamente la situación cultural y social de los pueblos indígenas de la actualidad en los libros de Estudios Sociales. De hecho, en los textos de esta asignatura predomina el interés por los pueblos indígenas prehispánicos y sus manifestaciones culturales (arquitectura, orfebrería, cerámica, patrones de asentamiento y de cultivo, religión, enterramientos, alimentación), así como por su extensión territorial en el pasado y la periodización de sus estadios culturales. Por este motivo, son pocos los libros que dedican algunas páginas a los pueblos indígenas del presente y, de hacerlo, en estas se orienta la exposición a los problemas socioeconómicos. En los textos de Español, por su parte, el tema está prácticamente ausente, a no ser por unas cuantas referencias al aporte léxico de las lenguas indoamericanas a las variedades locales del español americano.

En cualquier caso, la escasísima presencia de información acerca de los pueblos indígenas costarricenses del presente y a sus lenguas vernáculas nos revela el desinterés predominante en el sistema educativo por el patrimonio lingüístico costarricense y la diversidad étnico-idiomática del país. A fin de cuentas, pareciera que a este desinterés subyace la ideología expuesta con contundencia por Yglesias (1942) en cuanto a la nula relevancia de los indígenas costarricenses en la conformación de la identidad nacional, de modo que poco importa su especificad lingüística.

La escasa atención prestada a la lengua de señas costarricense (LESCO) y al inglés criollo limonense son sin duda manifestaciones de este mismo desinterés, a lo que se aúna que no hayan sido consideradas materia de estudio de los académicos hasta época relativamente reciente, en especial en lo que atañe a la lengua de señas. De hecho, los trabajos de descripción lingüística del LESCO han sido muy escasos (Retana 2011).

En los textos escolares, ninguno de los dos idiomas es mencionado, mientras que en los textos periodísticos la lengua de señas costarricense aparece ligada, más o menos a partir de la década de 1990, exclusivamente a las noticias sobre discapacidad y derechos de la población sorda a ser atendida en los servicios médicos y públicos en su propia lengua. Con anterioridad a esta época, las noticias versaban sobre la sordera y la necesidad de oralizar a los niños sordos. Por su parte, el inglés limonense si acaso se menciona de manera muy marginal y esporádica en las noticias sobre el calypso y otras manifestaciones culturales de los afrolimonenses. Todo esto nos proporciona una idea de las ideologías hegemónicas en el país con respecto a otros grupos culturales distintos al hispanocostarricense.

El análisis de las manifestaciones de las ideologías lingüísticas con respecto a las lenguas minoritarias de Costa Rica en las fuentes escritas seleccionadas para tal fin únicamente ha permitido detectar la existencia de dos complejos ideológicos y de varios ejes de expresión discursiva de estos. La elaboración de tales ejes es muy variable y depende sobre todo de la instancia emisora. Así, se trata de una elaboración bastante profunda en los textos de índole académica de finales del siglo XIX y en los primeros del siglo XX, pero es superficial en los textos periodísticos, y prácticamente nula en los textos escolares.

Además, los dos complejos ideológicos reconocidos no tienen igual presencia en las fuentes: el complejo de la relación entre identidad y lenguaje predomina en el discurso periodístico y en los textos académicos más recientes (sobre todo los de corte antropológico), 
mientras que el complejo de la jerarquía lingüística predomina en las crónicas de viaje y, en especial, en los textos académicos anteriores a la década de 1970. La vigencia y expresión de estos complejos en el discurso de personas "comunes" ha de abordarse como tema de investigación pormenorizada, al estilo de lo realizado en Sánchez (2012), con el fin de completar el panorama acerca de las ideologías lingüísticas sobre la diversidad idiomática de Costa Rica que se ha esbozado.

\section{Notas}

1. Deseo expresarles mi agradecimiento a Diego Ugalde por la revisión minuciosa del texto y de la bibliografía, a Lucía Zúñiga por su ayuda en la búsqueda y sistematización temática de los artículos de periódico, y a Luis Artavia Tencio por la búsqueda y selección de los textos escolares. Asimismo, deseo dejar constancia de mi agradecimiento al M.L. Henry Angulo por la revisión de la traducción del resumen al inglés.

2. Debemos enfatizar que no nos mueve el afán de desacreditar, desvalorar o descalificar las descripciones y teorizaciones de otros autores, sino que nuestro propósito consiste en analizar los esquemas ideológicos que subyacen al tratamiento, académico o no, de las lenguas minoritarias de Costa Rica. Al asumir una posición crítica con respecto al tema, por lo tanto, deseamos mostrar de qué manera funcionan nuestras ideologías en las valoraciones y representaciones sobre las variedades lingüísticas; es decir, proponemos un estudio crítico sobre conceptos, descripciones y generalizaciones, no un ataque a particulares o a instituciones.

3. No nos ocupamos, por lo tanto, de las lenguas de grupos de inmigrantes de origen asiático, africano, europeo, caribeño o estadounidense (v.g. inglés, francés, alemán, mandarín, cantonés, árabe, etc.).

4. Aunque en un principio se comenzó la búsqueda en todos los diarios del país, en el proceso -ante los resultados infructuosos que se obtenían- se decidió limitarla a La Nación y el Diario Extra. Básicamente, la decisión se tomó con base en la posibilidad de recurrir a las bases de datos digitales de tales diarios. Se encontraron 235 noticias relativas a los pueblos indígenas, 37 sobre la población sorda y 5 acerca de los afrolimonenses en el Diario Extra. En La Nación, se encontraron 526 noticias acerca de los pueblos indocostarricenses, 14 sobre los afrolimonenses y 19 sobre la población sorda. Las fechas van desde la década de 1950 hasta el año 2012.

5. Revisamos 76 textos para la enseñanza del Español en primaria y secundaria y 14 para la enseñanza de los Estudios Sociales también en ambos niveles. En los dos casos se trata de libros publicados a partir de la década de 1980 hasta el presente.

6. En todas las citas textuales, se respeta la ortografía original.

7. Citamos la traducción al español del informe original de Gabb (1875), recogido en Fernández (1883).

8. Además, Constenla detalla que se trata de un "fenómeno de grado" en cuanto a su presencia en los idiomas del mundo, por lo que todas las lenguas muestran con mayor o menor frecuencia mecanismos económicos de producción léxica, e indica que estos son de muy diversa índole (empleo de grupos sintácticos -el más regular y sencillo-, y procedimientos morfológicos tales como la composición y la derivación).

9. Así, la proliferación de términos distintos para codificar significados que, de algún modo, pueden considerarse muy relacionados, como suele ocurrir en español (por poner un caso, todo aquello que sirva de cubierta de una superficie: pelaje, musgo, escamas, corteza, plumas), se interpreta según este parámetro como un rasgo de mayor sofisticación lingüística frente a la alternativa de expresar estos mismos significados mediante la combinación de lexemas: uno que exprese el sentido de "cubierta de una superficie" y el otro que indique la superficie (de forma que, siguiendo el mismo ejemplo, se diga algo así como "cubierta del cuerpo humano", "cubierta de la piedra", "cubierta del pez", "cubierta del árbol”, "cubierta del ave"). El térraba, lengua que sirve como ejemplo paradigmático del "primitivismo" léxico en autores como Gagini y Pittier, se caracteriza precisamente por codificar muchas veces mediante una misma palabra, o por medio de composición o grupos nominales, lo que en español (y otros idiomas indoeuropeos) se codifica por medio de lexemas distintos (ver al respecto Constenla 2007). 
10. Quizás lo más preocupante es que la denominación "dialecto indígena” siga vigente en nuestros días y que sea empleada en documentos oficiales de instancias gubernamentales, como ocurre, por ejemplo, con el formulario vigente al 2013 para solicitar una beca del Fondo Nacional de Becas (FONABE), en cuya última página se indaga sobre la pertenencia del solicitante a un "grupo minoritario" mediante la pregunta "¿Puede el solicitante hablar un dialecto?”, seguida de la opción para marcar "¿Cuál o cuáles de los siguientes dialectos?", entre los que figuran las siguientes opciones: "Bribrî", "Cabécar", "Maleku o Guatuso”, "Boruca o Brunca", "Ngnöbe o guaymí", "Mekatelyo o inglés limonense", "Huetar", "Teribe o Térraba”.

\section{Bibliografía}

Acevedo Vargas, Jorge Luis. 1986. La música en las reservas indígenas de Costa Rica. San José: Editorial de la Universidad de Costa Rica.

Acosta Corella, Tito. 1953. "Primer seminario de las escuelas indígenas verificado en Boruca el 6 y 7 de febrero de 1953”. El maestro II. (14): 355-357.

Álvarez Navarro, Emilia et al. 1979. Análisis fonológicos y gramática generativotransformacional del maleku (guatuso). Trabajo final de graduación: Universidad de Costa Rica.

Arias Quirós, Ana Cecilia et al. (Eds.). 2003. II Congreso sobre pueblos indígenas. San José: Sección de Impresión del SIEDIN.

Arroyo Soto, Víctor Manuel. 1966. Lenguas Indígenas Costarricenses. San José: Editorial Costa Rica.

Baker, Colin. 1992. Attitudes and Language. Clevedon: Multilingual Matters.

Barrientos, Guido. 1993. Secretos de Talamanca. Una forma sana de vivir. San José: Centro de Estudios y Publicaciones Alforja.

Bauer, Laurie y Peter Trudgill (Eds.). 1998. Language Myths. Londres: Penguin.

Bernández, Enrique. 2004. ¿Qué son las lenguas? Madrid: Alianza.

Blen Jiménez, L. 2005. Nuevos destinos de Estudios Sociales 5. San José: Eduvisión.

Bozzoli de Wille, María Eugenia. 1969. Localidades indígenas costarricenses. San José: EDUCA.

1986. El indígena costarricense y su ambiente natural: Usos y adaptaciones. San José: Porvenir.

Bozzoli, María Eugenia e Isabel Wing-Ching S. 1979. Encuesta socioeconómica en la zona del P.H. Boruca. (mimeo).

Bozzoli, María Eugenia et al. (Comps.). 1998. Primer Congreso Científico sobre Pueblos Indígenas de Costa Rica y sus fronteras. San José: Editorial de la Universidad Estatal a Distancia.

Campomanes Fernández, Alfonso. 1980. Gramática generativo-transformacional del cabécar, oraciones compuestas coordinadas. Tesis de licenciatura: Universidad de Costa Rica.

Castro Mora, Ana et al. 1979. Gramática generativo transformacional de dialecto Nobere del guaymí. Tesis de licenciatura: Universidad de Costa Rica. 
Constenla Umaña, Adolfo. 1992. "Construcción posesiva y economía morfoléxica en las lenguas del Área Colombiano-Centroamericana”. Estudios de Lingüística Chibcha. 11: 101-114.

2004. "El estudio de las lenguas de la Baja Centroamérica desde el siglo XVI hasta el presente". Estudios de Lingüística Chibcha. 23: 9-58.

2007. La lengua de térraba. San José: Editorial de la Universidad de Costa Rica.

Constenla Umaña, Adolfo, Feliciano Elizondo Figueroa y Francisco Pereira Mora. 1998. Curso básico de bribri. San José: Editorial de la Universidad de Costa Rica.

Crystal, David. 1995. The Cambridge Encyclopedia of Language. Cambridge: Cambridge University Press.

Díaz Virgin, Beulah et al. Una gramática generativa transformacional de un idiolecto del broran (térraba). Tesis de licenciatura: Universidad de Costa Rica.

Dorian, Nancy. 1998. "Western language ideologies and small-language prospects". En: Grenoble y Whaley (Eds.), 3-21.

Eduvisión. 2008. Descubramos Costa Rica 5. San José: Eduvisión.

Fernández, León. 1883. Colección de documentos para la Historia de Costa Rica. Tomo III. San José: Imprenta Nacional.

Fernández Guardia, Ricardo. 2002. Costa Rica en el siglo XIX. Antología de viajeros. San José: Editorial de la Universidad Estatal a Distancia.

FONABE. Formulario para solicitar una beca. http://www.fonabe.go.cr/Becas/TiposBecas/ Paginas/Becas_poblacion_indigena.aspx.

Gabb, William. 1875. On the Indian tribes and languages of Costa Rica. Washington: Sthmisonian Museum.

1883. “Tribus y lenguas indígenas de Costa Rica”. En: Fernández, 303-485.

1895. Informe sobre la exploración de Talamanca verificada durante los años 1873 -74. San José: Imprenta Nacional.

Gagini, Carlos. 1917. Los aborígenes de Costa Rica. San José: Imprenta Trejos Hermanos.

Grenoble, Lenore A. y Lindsay J. Whaley (Eds.). 1998. Endangered Languages. Language loss and community response. Cambridge: Cambridge University Press.

Guevara Berger, Marcos y María Eugenia Bozzoli Vargas. 2002. Los indígenas costarricenses en el siglo XXI: Algunas perspectivas para la acción. San José: EUNED.

Guevara Berger, Marcos y Rubén Chacón Castro. 1992. Territorios indios en Costa Rica: Orígenes, situación actual y perspectivas. San José: García Hermanos.

Jara Murillo, Carla Victoria. 2006. El español de Costa Rica según los ticos. Un estudio de lingüística popular. San José: Editorial de la Universidad de Costa Rica.

Kohkemper M., Mainrad. 1955. Historia de las travesías de la cordillera de Talamanca. San José: Imprenta Nacional.

Kroskrity, Paul V. (Ed.). 2000a. Regimes of Language. Ideologies, Polities and Identities. Santa Fe: School of American Research Press. 
2000b. "Regimenting Languages. Language Ideological Perspectives". En: Kroskriy (Ed.), 1-34.

2000c. "Language Ideologies in the Expression and Representation of Arizona Tewa Identity”. En: Kroskriy (Ed.), 329-359.

Margery Peña, Enrique. 1989. Diccionario cabécar-españollespañol-cabécar. San José: Editorial de la Universidad de Costa Rica.

Mercier, Paul. 1976. Historia de la antropología. Barcelona: Península.

Mires, Fernando. 1991. El discurso de la indianidad. La cuestión indígena en América Latina. San José: DEI.

Moreno Cabrera, Juan Carlos. 2006. La dignidad e igualdad de las lenguas. Crítica a la discriminación lingüística. Madrid: Alianza.

Niedzielski, Nancy A. y Dennis R. Preston. 2003. Folk Linguistics. Berlín: Mouton de Gruyter.

Palmer, Paula (Coord.). 1983. Nuestra Talamanca...ayer y hoy. San José: Departamento de Publicaciones del Ministerio de Educación Pública.

Pittier, Henri. 1891. Viaje de exploración al Valle del Río Grande de Térraba. San José: Tipografía Nacional.

1895. Nombres geográficos de Costa Rica. I Talamanca (Primera Contribución). San José: Tipografía Nacional.

1897. Primera contribución para el estudio de las Razas indígenas de Costa Rica. San José: Tipografía Nacional.

1904. "Numeral Systems of the Costa Rican Indians". American Anthropologists. 6 (4): 447-458.

1938. Apuntaciones etnológicas sobre los indios bribris. San José: Imprenta Nacional. 1941. Materiales para el estudio de la Lengua Brunka hablada en Boruca recogidos en los años de 1892 a 1896. San José: Museo Nacional.

Pittier, Henri y Carlos Gagini. 1892. Ensayo lexicográfico sobre la lengua de Térraba. San José: Tipografía Nacional.

Pozas Arciniéga, Ricardo. 1920. Zàís ma7 isà巛 (Yo voy a decir). México: Ideal.

Quesada Pacheco, Miguel Ángel. 1992. El español en Costa Rica. Historia de sus estudios filológicos y lingüísticos. San José: Fernández-Arce.

2005. Fichas de Estudios sociales y Cívica para primaria. San José: LIL.

Retana Castro, Priscilla. 2011. "Aproximación a la lengua de señas costarricense (LESCO)". Revista de Filología y Lingüística. 37 (2):137-146.

Rodríguez, Maribel et al. 1983. "Escuelas indígenas efectúan la enseñanza del bribri”. En: Palmer (Coord.), 118-120.

Sánchez Avendaño, Carlos. 2012. "Los indios lo que hablan es un dialecto. Representaciones de los hispanos con respecto a los malecus y su lengua vernácula". Revista de Filología y Lingüística. 38 (2): 135-161. 
2013. "Lenguas en peligro en Costa Rica: Vitalidad, documentación y descripción”. Káñina. 37 (1): 219-250.

Santamaría, Marco Antonio et al. 1994. La enseñanza de los Estudios Sociales. San José: EUNED.

Schieffelin, Bambi B. 2000. "Introducing Kaluli Literacy. A Chronology of Influences". En: Kroskrity (Ed.), 293-327.

Schieffelin, Bambi B., Kathryn A. Woolard y Paul V. Kroskrity (Eds.). 1998. Language Ideologies. Practice and Theory. Oxford: Oxford University Press.

Schuller, Rudolf. 1927a. "La Posición Etnológica de los indios de Talamanca, Costa Rica, C.A.”. El maestro. 1 (5): 137-141.

1927b. "La Posición Etnológica de los indios de Talamanca, Costa Rica, C.A.”. El maestro. 1 (6): 177-180.

Stone, Doris. 1949. The Boruca of Costa Rica. Cambridge: The Museum of American Archaeology and Ethnology.

1961. Las tribus talamanqueñas de Costa Rica. San José: Museo Nacional de Costa Rica.

Thiel, Bernardo Augusto. 1882. Apuntes lexicográficos de las lenguas y dialectos de los indios de Costa Rica. San José: Imprenta Nacional.

Tusón, Jesús. 2010. Los prejuicios lingüísticos. Barcelona: Octaedro.

Von Frantzius, Alexander. 1925a. "Sobre los aborígenes de Costa Rica". Revista de Costa Rica. 6 (10): 218-220.

1925b. "Sobre los aborígenes de Costa Rica". Revista de Costa Rica. 6 (11): 225-234.

Wilson, Jack. 1996. Mitos del lenguaje. Expertos y autoridades. San José: Editorial de la Universidad de Costa Rica.

Woolard, Kathryn A. 1998. "Introduction. Language Ideology as a Field of Inquiry”. En: Schieffelin et al. (Eds.), 3-47.

Yglesias Hogan, Rubén. 1942. Nuestros aborígenes. Apuntes sobre la población precolombina de Costa Rica. San José: Trejos Hermanos.

Zeledón Cartín, Elías (Ed.). 1997. Viajes por la República de Costa Rica II. FrantziusHoffmann-Polakowsky. San José: Editorial del Servicio de Publicaciones del Ministerio de Cultura, Juventud y Deportes.

(Comp.). 2003. Crónicas de los viajes a Guatuso y Talamanca del Obispo Bernardo Augusto Thiel 1881-1895. San José: Editorial de la Universidad de Costa Rica.

\section{Textos periodísticos citados}

Ávalos Rodríguez, Ángela. 2000. "Censo en región indígena ¡Sa skena buay!”. La Nación (Noticias Nacionales). 29/06: 5A.

Cantero, Marcela. 2005. "Niña guaymí vence su sordera en las aulas de la Centeno Güell”. La Nación (Aldea Global). 29/04: 17A. 
Díaz, Doriam. 2007. "Lenguas indígenas en nuestro país están condenadas a morir”. La Nación (Aldea Global). 18/11. www.nacion.com/ln_ee/noviembre/18/ald/ea1319106.html

Flores, Luis Ángel. 2007. "Indígenas maleku reciben turistas en Palenque Tonjibe". Diario Extra (Espectáculos). 03/04. anteriores.diarioextra.com/2007/abril/03/espectaculos04. php.

Salguero, Miguel. 1963. "Las últimas huellas de los indios guatusos". La Nación (La vida en Tiquicia). 13/06: 20.

1970. “Ticos auténticos...que no hablan español”. La Nación (Gentes y Paisajes). 02/04: 32 .

1970. "El idioma y la escuela”. La Nación (Gentes y Paisajes). 04/05: 32.

1971. “Tanda de doce en Buenos Aires”. La Nación (Gentes y Paisajes). 23/05: 36.

1976. "Unidad de educación indígena". La Nación (Gentes y Paisajes). 06/05: 30.

Sin autor. 1953. "Interesantes observaciones meteorológicas y agropecuarias en la región indígena de Chirripó”. La Nación (Nacionales). 03/09: 24. 